\title{
FAMILY HOLDINGS PROFITABILITY IN THE ORGANIC FOOD PRODUCTION IN THE REPUBLIC OF SERBIA
}

\author{
Miljana Barjaktarović' , Boris Kuzman², Sonja Žarković3
}

\begin{abstract}
Summary
Transfer from conventional to organic production in its basis has the profitability analysis of this form of investment. The production of organic food is expensive, but the prices of organic products are high and organic food demand significantly increases every year. The profitability analysis of organic food investment includes a detailed analysis of many factors that have the influence on the final outcome of the investment. The production efficiency and rational usage of available resources of the privatelyowned farm was measured by calculating their profit using the calculation method of state agriculture subsidies and by evaluation of their own and borrowed resources involved in production. Accordingly, the work aims to encompass and analyze the most important factors of the investment and the impact of their changes on the profitability of organic food production in Serbia.
\end{abstract}

Key words: organic production, growth, profitability analysis, cost-benefit calculations JEL: $Q 1, M 4, M 11$

\section{Introduction}

Profitability of organic production can be analyzed in the context of the benefits of this way of manufacturing procedures compared to conventional (classical) production of agricultural products. It is generally known, and already established by scientific methods long time ago, that there are a number of positive effects of organic farming in the environmental, social and economic sense. Its main objective is the production of agricultural products that have a high level of quality. By now, there is a strong body of evidence showing that organic farming is more environmentally friendly: potential benefits from organic production arise from improved soil fertility, organic

1 Miljana Barjaktarović Ph.D., Full Professor, Alfa BK University, Palmira Toljatija Street no. 3, 11070 Belgrade, Serbia, Phone: +381 112699 039, E-mail: miljana.barjaktarovic@alfa.edu.rs

2 Boris Kuzman Ph.D., Associate Professor, Institute of Agricultural Economics, Volgina Street no. 15, 11060 Belgrade, Serbia, Phone: +381 63590 129, E-mail: kuzmanboris@yahoo.com

3 Sonja Žarković, M.A., Teaching Assistant, Alfa BK University, Palmira Toljatija Street no. 3, 11070 Belgrade, Serbia, Phone: +381 112699 039, E-mail: sonja.zarkovic@alfa.edu.rs

EP 2016 (63) 4 (1309-1322) 
matter content and biological activity; better soil structure and reduced susceptibility to erosion; reduced pollution from nutrient leaching and pesticides; and improved plant and animal biodiversity (Kasperczyk, Knickel, 2006).

Organic food production is rising worldwide over past decade. As of 2001, the estimated market value of certified organic products was estimated to be $\$ 20$ billion. By 2012 the market had reached $\$ 63$ billion worldwide. (Willer, Lernoud, Home, 2013). It is practiced in approx. 154 countries spread over five continents, in an agricultural area of approx. 31.584.720 ha, of which 42.9\% in Oceania (Australia), 23.8\% in Europe, 23.5\% in Latin America, 5.5\% North America, 2.8\% in Asia and 1.6\% in Africa. In Europe, there are run approx. 7.6 million ha of environmental management in approx. 178940 farms today, of which Austria 12.9\%, Finland 7.22\%, Italy 6.86\%, Sweden 6.8\%, Greece 6.24\%, Denmark 6.2\%, 5.97\% Czech Republic, Estonia 4.59\%, Slovenia 4.6\%, UK 4.42\%, Germany $4.3 \%$. Organic products in the world market are about 3.1 to $4.3 \%$ (Movileanu, Movileanu, Sasu, 2013). The demand for organic products in the EU (especially in Western Europe), shows the continued growth ranging from 20-25\% annually (the estimates are that the share of organic food market will be 5\% comparing to conventional food). Germany and France have the largest organic food market in Europe. A bit smaller one is recorded in Denmark, the Netherlands, Austria, Switzerland and other countries.

The cost-effective analysis of organic production was carried out by a few universities form the USA and Europe under the title: Comparative Analysis of Organic and Nonorganic Farming System: a Critical Assessment of Farm Profitability and it gave the following results (Nemes, 2009):

- The overwhelming majority of cases show that organic farms are more economically profitable, despite of frequent yield decrease;

- Organic crop yields are higher in cases of bio-physical stress (e.g. drought);

- The higher outcomes generated by organic agriculture are due to premium prices and predominantly lower production costs;

- The different value and accountability given to labour costs, including both hired and family labour, differs through countries, thus yielding to opposite results;

- The major difference in the profitability of the two systems is very often determined by the different management skills of the farmers thus, accounting for these seem to be fundamental for correct interpretations of results;

- There is a wide range of discrepancies among studies related to what variable and fixed costs entail and without agreeing upon which input costs shall be included under which circumstances in economic studies, no clear-cut conclusion on profitability can be drawn when analyzing available literature.

The analysis showed that in the majority of cases, organic production is more profitable than the conventional one. There are wide variations among yields and production costs, but either higher market price and premiums, or lower production costs, or the 
combination of these two generally result in higher relative profit in organic agriculture in developed countries. The same conclusion can be drawn from studies in developing countries but there, higher yields combined with high premiums are the underlying cause for higher relative profitability. (Nemes, 2009).

State subsidies are also a very important profitability factor when it comes to conventional wheat production. Namely, without state subsidies family farms are not profitable, only the farms of more than 82.13 ha in size are profitable (Munćan, Todorović, Munćan, 2014).

Due to the high demand on the one side, and high pollution of soil, water and air, disturbed ecosystems (being agro-ecological preconditions for the development of organic agriculture), there is a possibility and opportunity for poorer countries and countries in transition (which still have preserved agricultural system), to increase their exports by organic products and seize leadership position in the production of organic food. For the time being this opportunity is recognized by certain countries, one of them being Hungary, which exports $80 \%$ of its products and is the most successful country in terms of exports of organic agriculture products in Europe. Almost all developing countries, especially in transition, are characterized as -markers in development of organic food. (Lukić, 2011). Analysis of the effectiveness of the organization and functioning of most developed world markets organic food - through the relevant literature is the assumption for improving market efficiency in the development of organic food (Raynolds, 2004).

\section{Methods of research and sources of data}

The material used for the study undertaken found in research, data analysis and interpretation of the scientific national and foreign literature, statistical reports published by the Statistical Office of the Republic Serbia and other sources of data collected from Belgrade Chamber of Commerce, National Association for Organic Farming Development - Serbia Organica, about the importance and management of organic production.

As the task of method analysis profitability and cost-benefit calculations is to analyze and explain important economic issues that economic agents deal with on a day-to-day basis, it is used here as an indicator of cost-effectiveness of organic wheat production compared to the conventional production. The data is gathered and analyzed as such, based on organic and conventional wheat producers' experiences and market research (statistical data, interview with the owner of family farm "Mamužić", analysis of the price of wheat on the Commodity Exchange in Novi Sad, market research of retails sales of organic wheat). The production and cost analysis in farms makes the consideration of the extent of trading success possible, and as such it gives options and possibilities to improve the achieved level of success. 


\section{Results and discussion}

Based on the gathered data, the achieved economic results of two wheat production models are shown. One model is the conventional wheat production, and the other one is organic. It is widely known that yield is smaller with the organic production in comparison to the conventional, which can be seen in Table 2. where conventional production yield is $4,3 \mathrm{t} / \mathrm{ha}$ and organic production yield is $4 \mathrm{t} / \mathrm{ha}$. Precisely because of such a low yield with higher nutritional value and other positive characteristics the organic wheat has a higher market price. As a result of higher organic wheat price we have a higher income, as an achieved sales profit. However, in the course of this study the data obtained showed that subsidies, which are double for the organic production, have the influence on the increase in the final organic wheat profit. Accordingly, the price of organic wheat production is not the key factor in the total income formation because the organic product market is still underdeveloped and the purchasing power of the population is low, therefore, the producers still have the motivation to get the subsidies for organic production.

As in any economic analysis, an income is not a key factor for making business decisions. Costs have also a significant role. In this study costs are classified into two groups. The first group are variable (intermediate goods, the use of machinery etc.) and the second are fixed costs (maintenance and amortization of machinery and facilities, land rent, loans and so on). Including all the relevant costs and incomes into the gross margin account, the obtained results show that conventional wheat production is highly unprofitable on the 10 ha, 20 ha and 30 ha land areas, whereas with the organic production we have a positive result on those areas. We can conclude that cost-effectiveness of organic wheat production is significantly higher than with the conventional wheat production.

\section{The production potential of Serbia in organic food production}

Organic agriculture is now widely recognized by the public and governments as a valid alternative to conventional agriculture and is a source of ideas and approaches that conventional agriculture can adopt to make it more sustainable (Kristiansen, Acram, Reganold, 2006). Agricultural development organizations such as IFAD, FAO and NGOs are becoming open to the idea that organic agriculture should be considered as one beneficial development pathway for smallholder farmers (Halberg, Alroe, Kristensen, 2006). During 2013, compared to the previous year, organic agricultural land area in Serbia increased by $32 \%$ to 8.228 ha (the area in the switch period about 5.041 ha, organic status about 3.187 ha) (Povećane površine pod organskom proizvodnjom, 2014). This kind of production is mostly present in Vojvodina and Šumadija, but it also makes a significant growth in the western and southern Serbia. According to the plans of the Ministry of Agriculture, Forestry and Water Management of Serbia, till the year 2014 there should be 50,000 ha under organic production, while the ambition of the Ministry for a longer period is 600,000 ha (Privredna komora Beograda, 2014).

Serbia has a significant potential to become one of the most important producers of 
organic food in Europe. Relatively clean soil (with a short period of adjustment, between 2 and 3 years) and the surface where all sorts of plants can be grown (crops, vegetable and fruit), harvested and cultivated medicinal plants and wild fruits, developed livestock and bee production, create a large production potential of Serbia in organic agriculture, unlike the conventional, which is still primary. In fact, 97\% of agricultural production is based on conventional production of products for human and animal nutrition. The collapse of the Serbian economy and the closure of factories in Serbia which lasted for years, led to the fact that the natural resources and the land itself are being revitalized from a variety of hazardous and toxic substances. Such a revitalized land becomes perfectly suitable for the organization of organic production. However, a significant role in the farmer's decision to shift from conventional to organic production has the support and assistance of the state through the relevant ministry in the form of various subsidies, donations, education, etc.

According to the Decree of the Council of Europe, the switch from conventional to organic production needs a transitional period of another five years to clean the soil from harmful substances. The European Union awarded grants in the amount of EUR 600 per ha for one year to EUR 900 per ha for perennial arable crops. However, in Serbia subsidies range from EUR 300-600. It should be mentioned that last year the state allocated from its budget about RSD 400 million to boost organic farming, which is ten times more than in the previous year, and not to mention that the new law on organic production prescribe measures for the development of domestic organic food market, production and export increase encouragement, as well as counselor education.

The concrete results of the development of organic agriculture in Serbia are shown in a research study "Organic Agriculture in Serbia" published in January 2012. ${ }^{4}$ The results of the study indicate a low ratio of surface where the organic food is grown related to the total agricultural land, as well as a small number of crops that are grown. By comparing the data on the total agricultural area and the area of organic agriculture in Serbia in the broadest sense of understanding, we get the information of only $0.04 \%$ of the share size in organic agriculture in relation to the total agricultural land which puts Serbia to the category of countries with the lowest percentage share.

Table 1. Areas in the system of organic farming in Serbia by culture (2012)

\begin{tabular}{|l|l|r|r|r|}
\hline Product category & Agricultural crops & \multicolumn{1}{|c|}{$\begin{array}{c}\text { Organic } \\
\text { production (ha) }\end{array}$} & $\begin{array}{c}\text { Switch period } \\
\text { (ha) }\end{array}$ & Total (ha) \\
\hline & Apples & $1,177.55$ & 6.02 & $1,183.57$ \\
Perennial fruit plant & 550.00 & 142.46 & 682.46 \\
species & Raspberries & 41.42 & 11.54 & 52.96 \\
& Strawberries & $1,188.56$ & 39.48 & $1,228.04$ \\
& Plums & 409.94 & 26.38 & 436.32 \\
& Sour cherries & 686.53 & 865.31 & $1,551.84$ \\
\hline
\end{tabular}

4 Project holders: Deutsche Gesellschaft fur Technische Zusammenarbeit-GTZ and Institut FIBL-a (Institute of Organic Agriculture).

EP 2016 (63) 4 (1309-1322) 


\begin{tabular}{|c|c|c|c|c|}
\hline $\begin{array}{l}\text { Total for the } \\
\text { category }\end{array}$ & & $4,054.00$ & 1,091.19 & $5,145.19$ \\
\hline One year plants & $\begin{array}{l}\text { Com } \\
\text { Wheat } \\
\text { Soybean } \\
\text { Total: } \\
\text { Vegetables etc. }\end{array}$ & $\begin{array}{r}280.37 \\
284.66 \\
104.53 \\
669.56 \\
296.5 \\
\end{array}$ & $\begin{array}{r}539.33 \\
28172 \\
39.50 \\
860.55 \\
233.00\end{array}$ & $\begin{array}{r}819.70 \\
566.38 \\
144.03 \\
1,530.11 \\
529.50\end{array}$ \\
\hline Other crops & & $2,181.47$ & 873.74 & $3,055.21$ \\
\hline $\begin{array}{l}\text { Total for the } \\
\text { category }\end{array}$ & & $3,147.53$ & $1,967.29$ & $5,114.82$ \\
\hline Pastures & & 20.83 & 818.97 & 839.70 \\
\hline
\end{tabular}

Source: Organska poljoprivreda u Srbiji 2013. Serbia organica. January 2013, p.13.

As it can be seen from the table, from the total area under organic production, perennial plant species can be grown on about $46.7 \%$, and one-year plants on about $46 \%$ of area. The remaining area $(7.3 \%)$ is meadows and pastures. Within the category of perennial species, predominately apples and plums are grown, as well as berries, especially raspberries. Grains, soybeans, and vegetables are the main one-year species. Although the berries are the main export species, it seems that farmers are opting for other species, mainly apples and plums (as shown in the table). Also, there is a significant increase in the kinds of surfaces under the one-year plants, in particular corn and wheat.

The main manufacturing areas are the southern and western part of Serbia, as well as the entire territory of Vojvodina. Perennial crops are dominant within about $60 \%$ of the total organic agricultural land with $15 \%$ engaged in the production of perennial crops and $25 \%$ in the form of pasture. General characteristics of the agricultural production in Serbia, which is reflected in the fragmentation of farms and a large number of farmers, are present in the sector of organic agriculture. Around 3,000 manufacturers were engaged in this type of production in 2009, with expert assessments of the total value of products leaving the farm in the range between 20 - 25 million EUR. Considering this fact, the question is whether the organic farming is economically viable, to what extent and for how long.

\section{Analysis of the profitability of organic wheat production}

The importance of the economic viability of organic farming for each producer is not necessary to explain. However, it must be highlighted that a common mistake lies in the fact that the winning side does not include all effects of the transition to organic production. The classical calculation is based on a comparison of the revenue at the parole unit area (usually $1 \mathrm{ha}$ ) in conventional production, with the total variable costs in order to obtain margin coverage. The same procedure is repeated for organic production, and then it is observed the difference in the obtained cover margins. The main disadvantage of this kind of cost-benefit calculations is that the additional effects of organic farming, such as soil quality improvement for example, do not take into 
account. (Sudarević, 2013).

For the establishment of organic production is necessary to achieve the spatial isolation of land plots and farms from potential sources of pollution (pesticides, sewage, pollen of genetically modified crops etc.), a plot of land on which the content of harmful substances do not exceed the prescribed maximum amounts, prescribed water quality for irrigation and air. The inclusion of plots of land in organic farming is done on the condition that it is not used in the last two or three years for perennial plants or used without the application of substances of synthetic chemical origin. If the plot using funds used substances of synthetic chemical origin, it can be incorporated into organic farming by the end of the transitional period (conversion) of two or three years.

Opinions differ regarding the economic profitability of organic production. Organically produced food is a very lucrative business, but it is subject to various factors of risk. The opponents to the organic farming argue that organic products are more expensive than those from conventional production. This is true only if viewed superficially. Higher prices for organic products were primarily due to the fact that higher workforce engagement in developed countries is very expensive, and on the other side, these products are scarce on the market, which certainly affects the level of prices. However, if we examine further, the prices of products from conventional production are far higher than we pay directly, and so the price of organic products.

This finding justifies the claim that does not take into account the cost of treatment of people with various diseases, then cleaning watercourses from pesticides, restoring soil fertility due to loss of organic carbon whose content in the soil in the last 20 years is halved. It is obvious that the consumer paid far more expensive products from conventional production because their hidden cost is much higher.

Eighteen-year study at the University of Minnesota, resulted in data indicating that organic farming is more profitable and with less risk of return compared to conventional production (study related to the production of corn and soybeans). What gives organic production value in this case was not the yield, but the premium price (state subsidies). For example, the net return on a two-year, conventional corn - soybean crop rotation on average 342 USD per acre, compared to 267 USD per acre for the four-year organic rotation (corn/soybeans/oats/alfa-alfa), and 273 USD for four years of the conventional. However, when it received full organic premium, the average net return from organic production rose to 538 USD per acre, significantly outperforming the conventional systems both in terms of profitability and risk (Poljoprivredni standardi, 2011). Organic premium rates are often the main reason why farmers think about switching to organic production, as it is the case in the United States. Our rates are much lower, but still sufficient incentive for Serbian farmers.

Production factors of a farm, in practice, change over time, to a greater or lesser degree. These changes usually occur in the size and quality of production capacity, the yield, norms of expenditure of capital and labor, the amount and ratio of market prices of inputs and outputs and their movements over a longer period. For certain lines of agricultural 
production it is necessary to calculate the amount of the cost per unit resulting products, i.e. their cost (Sredojević, 2010). Reducing unnecessary costs affect on reducing cost, increasing the difference between the sales price of their own products or services and the cost, i.e. increases its profits (Hristov, 2012).

Organic farming is a form of agriculture with less investment and greater cost reduction. Farmer, who switches to organic farming, can effectively reduce costs, for example, recycling the largest possible amount of material on the farm. Labour costs can be reduced by using preventive measures to protect against diseases, pests and weeds. The investment costs can be reduced by using local plants to prepare their own pesticides, animal production for its own production of fertilizers, milk, eggs and meat, as well as by manufacturing of animal feed, sharing equipment and machinery with neighbours and so on. One of the important issues related to organic production are the economic effects of organic farms compared to conventional farms. The problem with this comparison is a methodological approach. The most appropriate approach would be to compare the existing conventional farm with the situation of a few years of organic farming. This approach is not very practical. There is a more adequate comparison of economies of organic and conventional production is to look at the differences between similar farms in terms of resources, production capabilities in land and other productive units (Mirecki, Wehinger, 2011).

Based on examples relating to the comparison of conventional/organic wheat production, it could be seen the profitability of organic wheat in Serbia:

Table 2. Calculation total income sale wheat

\begin{tabular}{|l|c|c|c|c|}
\hline \multicolumn{1}{|c|}{ Yield } & \multicolumn{2}{c|}{ Price (EUR/t) } & Conventional & Organic \\
\hline INCOME & Conventional & Organic & Yield 4,3t/ha & Yield 4t/ha \\
\hline Wheat (main product) & 188,41 & 655,35 & 810,163 & $2.621,4$ \\
\hline Primes (by-product) & 80 & 80 & $(\mathrm{x} 5,16 \mathrm{t}) 412,8$ & $(\mathrm{x} 4,4 \mathrm{t}) 352$ \\
\hline 1. TOTAL INCOMtion) & 130 & 350 & 130 & 350 \\
\hline
\end{tabular}

Source: calculation by authors according to data from: Statistical Yearbook of the Repulic of Serbia, 2014; Vodič za organsku proizvodnju pšenice, 2012.

Table 2, shows the yield in the production of conventional wheat $4,3 \mathrm{t} / \mathrm{ha}$, which is taken as the average amount based on statistical data. In the period from 2011 to 2013 year, its movement in Serbia was of 4-4,8 t/ha. (Statistical Yearbook of the Repulic of Serbia, 2014). According to (Hristov, Jevtić et al., 2012) yield of organic wheat in Serbia is around $4 \mathrm{t} / \mathrm{h}$. Based on telephone interview with the owner of the family farm "Mamužić", the obtained data indicate that the achieved yield of organic wheat in recent years on that family farm is from 4,5-6,5 t/ha, depending on several factors (weather, land preparation before planting, wheat variety, the quantity of mineral fertilizers and the use of new organic fertilizers, crop rotation, etc.).

The purchase price for the conventional wheat was taken from the Commodity 
Exchange, Novi Sad on 11.12.2014. On that day it was 23 dinars per kg, WAT not included. The purchase price of organic wheat was obtained directly from the producer i.e. Family farm "Mamužić", and it was 80 dinars per $\mathrm{kg}$. The same organic wheat purchase wholesale price was obtained from "Biošpajz", organic food store, Belgrade.

Ratio grain: straw, for conventional production is $1: 1,2$ for organic production is $1: 1,1$ therefore we can calculate the grain: straw ratio for 4,3t of conventional and $4 \mathrm{t}$ of organic yield. As a result of that ratio we got 5,16t of straw for the conventional and $4,4 \mathrm{t}$ for the organic product. Multiplied by the price, which is the same for both the conventional and organic straw, we get the value of 412,8 and 352 EUR (Višković, Golub, at al., 2012) and data gathered at the family farm "Mamužić".

Table 3. Calculation variable costs and marginal result in wheat production

\begin{tabular}{|c|c|c|c|}
\hline \multicolumn{2}{|c|}{ Elements } & $\begin{array}{l}\text { Conventional } \\
\text { Yield 4,3t/ha } \\
\end{array}$ & $\begin{array}{c}\text { Organic } \\
\text { Yield 4t/ha }\end{array}$ \\
\hline \multicolumn{2}{|l|}{ 1.TOTAL INCOME } & $1.352,963$ & $3.323,4$ \\
\hline Seeds (mechanized seeding) & $\begin{array}{l}\text { 250kg.x0,4 EUR convent. } \\
\text { 250kg.x0,8 EUR organ. }\end{array}$ & 100 & 200 \\
\hline $\begin{array}{l}\text { Variable costs for } \\
\text { mechanization and fertilizer } \\
\text { dispersing }\end{array}$ & $\begin{array}{l}\text { Additional costs for fertilizer } \\
\text { dispersion and weed control }\end{array}$ & 50 & 80 \\
\hline Harvest & 150EUR/ha & 150 & 150 \\
\hline Artificial fertilizers & $\begin{array}{l}\mathrm{N} 0,3 \mathrm{EUR} \times 25 \mathrm{~kg} / \mathrm{t}=7,5 \mathrm{EUR} / \mathrm{t} \\
\mathrm{P} 0,3 \mathrm{EUR} \times 15 \mathrm{~kg} / \mathrm{t}=4,5 \mathrm{EUR} / \mathrm{t} \\
\mathrm{K} 0,9 \mathrm{EUR} \times 24 \mathrm{~kg} / \mathrm{t}=21,6 \mathrm{EUR} / \mathrm{t} \\
\text { Total: }\end{array}$ & $\begin{array}{l}32,25 \\
19,35 \\
\underline{92,88} \\
144,48\end{array}$ & $\begin{array}{c}30 \\
18 \\
\underline{86,4} \\
134,4\end{array}$ \\
\hline Pesticides & 15EUR/ha & 15 & 0 \\
\hline Loan interest costs & $10,62 \%$ annual. (for 12 months) & 117 & 146 \\
\hline \multicolumn{2}{|c|}{ 2.TOTAL VARIABLE COSTS WITH INTEREST } & 576,48 & 710,4 \\
\hline \multicolumn{2}{|c|}{ 3.MARGINAL RESULT (has to cover other costs) (1-2) } & 776,483 & 2.613 \\
\hline
\end{tabular}

Source: calculation by authors according to data from: Statistical Yearbook of the Repulic of Serbia, 2014; Vodič za organsku proizvodnju p̌̌enice, 2012.

Note: $\mathrm{N}$ - Nitrogen, $\mathrm{P}$ - Phosphorus, $\mathrm{K}$ - Potassium. Average amounts of NPK for $1 \mathrm{t}$ of wheat yields are: $20-30 \mathrm{~kg} \mathrm{~N}, 12-18 \mathrm{~kg}$ P and $18-30 \mathrm{~kg} \mathrm{~K}$. The ratio between $\mathrm{N}: \mathrm{P}: \mathrm{K}$ should be 1 : $0.6-0.8: 0.4-0.6$. The average values have been taken in the paper. After the interview with the owner of the family farm "Mamužić", the ratio of the mineral fertilizers for organic wheat should be moving in the range of $15-25 \mathrm{~kg} / \mathrm{t}$, which coincides with the ratio in the production of conventional wheat (Pšenica- Triticum Sp.L, 2014)

Note: ProCredit Bank, ProAgro loan, annual effective interest rate 10,62 \%. The loan is designed for obtaining the seed, artificial fertilizers, pesticides, as well as the machinery and wheat silos. 
Table 4. Calculation fixed costs and expected total profit in wheat production

\begin{tabular}{|c|c|c|}
\hline \multicolumn{2}{|l|}{ Elements } & \multirow{2}{*}{$\begin{array}{r}\text { Sum } \\
5.000 \text { EUR } \\
846 \text { EUR }\end{array}$} \\
\hline $\begin{array}{l}\text { Machinery (depreciation } 10 \text { years, interest rate for } \\
\text { purchase } 10,62 \% \text { for } 50.000 \mathrm{EUR} \text { ) }\end{array}$ & $\begin{array}{l}\text { Depreciation } \\
\text { Interest }\end{array}$ & \\
\hline \multicolumn{2}{|l|}{ Total costs for machinery (year) } & 5.846 EUR \\
\hline $\begin{array}{l}\text { Fixed assets (grain silo/depreciation period } 40 \text { years., } \\
\text { purchased by } 10,62 \% \text { interest loan for } 20.000 \mathrm{EUR} \text { ) }\end{array}$ & $\begin{array}{l}\text { Depreciation } \\
\text { Interest }\end{array}$ & $\begin{array}{l}500 \text { EUR } \\
339 \text { EUR }\end{array}$ \\
\hline \multicolumn{2}{|l|}{ Total fixed assets, installations and buildings } & 839 EUR \\
\hline \multicolumn{2}{|l|}{ FIXED COSTS } & 6.685 EUR \\
\hline \multicolumn{2}{|l|}{ Fixed cost land lease (year) } & $250 \mathrm{EUR} / \mathrm{ha}$ \\
\hline $\begin{array}{l}\text { Fixed cost for farm } 10 \mathrm{ha} \\
\text { Fixed cost for farm } 20 \mathrm{ha} \\
\text { Fixed cost for farm } 30 \mathrm{ha}\end{array}$ & $\begin{array}{l}6.685 / 10+250 \\
6.685 / 20+250 \\
6.685 / 30+250\end{array}$ & $\begin{array}{r}918,5 \mathrm{EUR} / \mathrm{ha} \\
584,25 \mathrm{EUR} / \mathrm{ha} \\
472,83 / \mathrm{EUR} / \mathrm{ha}\end{array}$ \\
\hline Elements & $\begin{array}{c}\text { Conventional } \\
\text { Yield 4,3t/ha }\end{array}$ & $\begin{array}{l}\text { Organic } \\
\text { Yield 4t/ha }\end{array}$ \\
\hline 1.MARGINAL RESULT & 776,483 & 2.613 \\
\hline \multicolumn{3}{|l|}{ 2.FIXED COSTS } \\
\hline $\begin{array}{l}\text { For } 10 \mathrm{ha} \\
\text { For } 20 \mathrm{ha} \\
\text { For } 30 \mathrm{ha}\end{array}$ & $\begin{array}{r}918,5 \\
584,25 \\
472,83\end{array}$ & $\begin{array}{r}918,5 \\
584,25 \\
472,83\end{array}$ \\
\hline \multicolumn{3}{|l|}{ 3.EXPECTED TOTAL PROFIT / LOSS for farm of (1-2) } \\
\hline $\begin{array}{l}\text { 10ha } \\
20 \text { ha } \\
30 \text { ha }\end{array}$ & $\begin{array}{l}-142,017 \text { EUR } \\
+192,233 \text { EUR } \\
+303,653 \text { EUR }\end{array}$ & $\begin{array}{r}+1.694,5 \text { EUR } \\
+2.028,75 \text { EUR } \\
+2.140,17 \text { EUR }\end{array}$ \\
\hline
\end{tabular}

Source: calculation by authors according to data from: Pro Credit Bank, 2014; Statistical Yearbook of the Repulic of Serbia, 2014; Vodič za organsku proizvodnju pšenice, 2012.

Note: Amortization was calculated using the linear i.e. time method of writing off.

Note: Land - presumption of land rent-annual rent is 250EUR/ha.

The calculation presented above shows that organic production is more cost effective than conventional. The expected total profit for all three areas, expressed in hectares in organic production is far greater than conventional, which can be very important motivating reason for each manufacturer. The appearance of a negative result and lower profit in conventional production is the result of large fixed costs that the manufacturer has to cover. If we consider a slightly different situation that differs from this by the fact that the producer does not have the cost of renting land and somewhat less cost of property and equipment (if they already have in their possession, no loan or interest), then we can say that conventional production is profitable on the surface of 10 ha.

It is obvious that the benefits of organic farming are in favour of higher selling prices and higher subsidies. In a given calculation it was assumed that the yield per ha is different, which is normal. It is well known that the yield in organic production is less, so we saw that the gross margin of organic production is higher than the gross margin of conventional production. 
It is necessary to take into account the time frame because it often happens that the improvement in economic performance is directly related to a costly investment, either in new machines that require the amortization period to 10 years (e.g., tractor) or up to 20 years or even longer for buildings. Besides the time frame it is necessary to take into account another important aspect, partly defined steps of farm economic performance.

Access to the partly defined steps of a farm economy takes into account the fact that agricultural production follows the rule that existing resources (e.g. natural resources, labour and capital (land, buildings and equipment) should be used productively until input costs are equal to the price of the final product.

The basic rule of the intensity of production leads us to the fundamental assumption that if a farmer invests in production (e.g. labour power, land, equipment, buildings) creating a fixed cost, then you will need to use the full potential of its resources, where the cost of the last unit of input to be equal to the price of final production unit. This creates an optimal ratio of cost - profit. The cost of organic production are similar in cost to conventional, it could be seen in the example calculations are only allowed to vary in some areas, such as the system of cultivation, seed security, protection and nutrition, etc. However, when the yield is in question, then the conventional production is dominating, as it can be seen in the following table:

Table 5. Summary of yield of organic farming versus conventional

\begin{tabular}{|l|c|c|c|}
\hline \multicolumn{1}{|c|}{ Product unite / crop } & Unite & $\begin{array}{c}\text { Yield in \% on a } \\
\text { organic farm }\end{array}$ & $\begin{array}{c}\text { Yield in \% on a } \\
\text { conventional farm }\end{array}$ \\
\hline Wheat & $\mathrm{t} / \mathrm{ha}$ & 60 & 100 \\
\hline Vegetable (extensive crops) & $\mathrm{t} / \mathrm{ha}$ & 80 & 100 \\
\hline Vegetables (intensive crops) & $\mathrm{t} / \mathrm{ha}$ & 50 & 100 \\
\hline Potato & $\mathrm{t} / \mathrm{ha}$ & $30-70$ & 100 \\
\hline Sugar beet & $\mathrm{t} / \mathrm{ha}$ & $80-100$ & 100 \\
\hline Pasture (intensive) & Energy unit/ha & $60-70$ & 100 \\
\hline Leguminousus, i.e. Alfalfa & Energy unit/ha & $80-100$ & 100 \\
\hline Corn, silage corn & Energy unit/ha & $50-80$ & 100 \\
\hline
\end{tabular}

Source: Priručnik za organsku proizvodnju za poljoprivredne proizvođače, Food and Agriculture Organization of United Nations (FAO), Biotehnički fakultet, Podgorica, 2011, p.104.

And if the yield is dominated by the conventional manufacturing, as it is presented in the table, the organic farming production comes ahead of conventional production, when the benefit and the usage are taken into account.

\section{Conclusion}

Intensifying the development of organic agriculture aims to improve the quality of the food, health and life, to preserve the ecosystem, maintain and improve soil fertility and 
create the basis for sustainable agriculture development, maximize the use of renewable energy, environmental protection, reducing all forms of pollution etc. Organic farming is fully controlled manufacture. Although it contains only about $1 \%$ of the world food market, organic products are becoming increasingly sought after in the world and the share of these products in global trade flows is increasing. Organic products are evermore present on the shelves of retail chains in Serbia, and their sales are growing even though the price of these products is several times higher than non- organic. The greatest demand is for fresh products, i.e. for fresh fruits and vegetables.

To make organic farming acceptable to producers, i.e. farmers, not only motivation, but also economical aspects play important role. Farmers are currently stimulated by the premium prices in the organization of organic farming, which are currently higher than for conventional products. With such a high premium prices, there is the question of cost-effectiveness of organic farming. Various analysis and calculations, lead to the conclusion that organic production can be cost-effective compared to conventional. And not only is it profitable, but is also suitable for our farmers, as the Serbian farmer owns less arable land, which are suitable for the production of organic products.

\section{References}

1. Halberg, N., Alroe, F.H., Kristensen E.S. (2006): Synthesis: prospects for organic agriculture in a global context, at the book - Global Development of Organic Agriculture: Challenges and Prospect, pp. 344-364, CABI International Publishing, Oxfordshire, United Kingdom (available at: http:/hugo.alroe.dk/files/Work/2006Halberg_Alroe_Kristensen-Synthesis Prospects for organic agriculture in a global context-offprint.pdf, retrived 12.05.2015.)

2. Hristov, N., Jevtić, R., Lalošević, M. Franeta, F., Rajković, M. (2012): Vodič za organsku proizvodnju pšenice, Institut za ratarstvo i povrtarstvo, Novi Sad

3. Hristov, N. (2012): Vodič za organsku proizvodnju pšenice, GIZ-Nemačka organizacija za internacionalnu saradnju $\mathrm{GmbH}$, Novi Sad i Institut za ratarstvo i povrtarstvo, Novi Sad

4. Kasperczyk N., Knickel K. (2006): Environmental Impacts of Organic Farming. In: Kristiansen P.(ed.) Organic agriculture: a global perspective. CSIRO, Clyton, Australia, pp. 259-282

5. Kristiansen, P., Acram, T., Reganold, J. (2006): Organic Agriculture: A Global Perspective, CSIRO Publishing, Clyton, Australia, pp. 484, available at: http:// orgprints.org/14043/1/14043.pdf ( retrived 18.06.2015.)

6. Lukic, R. (2011). Estimates of economic performance of organic food retail trade, Ekonomska istraživanja, vol. 24, no. 3, pp. 157-169, Pula, Croatia

7. FAO (2011): Priručnik za organsku proizvodnju, Mirecki, N., Wehinger, T., Rome, available at: http://www.fao.org/docrep/015/an443sr/an443sr00.pdf)avalable 13.08.2015.) 
8. March, U., Kalentić, M., Stefanović, E., Simić, I. (2013): Organska poljoprivreda u Srbiji 2013, pp. 56, Serbia Organica, Beograd (available at: http://www. serbiaorganica.info/wp-content/uploads/2013/01/OPS FINAL srb.pdf, retrived $\underline{20.08 .2015)}$

9. Movileanu, P., Movileanu, V., Sasu, S. (2013): The market of Organic Food Production in Republic Moldova, Economic Engineering in Agriculture and Rural Development vol. 13, no. 2, pp. 269-272, Universitatea Agrară de Stat din Moldova, Moldova

10. Munćan, P., Todorović, S, Munćan, M. (2014): Profitability of Family Farms Directed at Corp Production, Economics of Agriculture vol. 61, no 3, pp. 575-585, Belgrade

11. Nemes, N. (2009): Comparative Analysis of Organic and Non-organic Farming System: a Critical Assessment of Farm Profitability, FAO, Rome, Italy

12. Oljača, S. (2012): Organska poljoprivredna proizvodnja, Zadužbina Andrejević, Beograd.

13. Raynolds, L.T. (2004): The Globalization of Organic Agro-Food Networks, World Development, vol. 32, no. 5, pp. 725-743.

14. Sredojević Z. (2010): Organizacija i isplativost organske proizvodnje. Zbornik radova - Četvrti forum o organskoj proizvodnji, Centar za organsku proizvodnju; Selenča, pp. 20-23, (available at: https://bs.scribd.com/doc/198550552/ Organizacija-i-Isplativost-Organske-Proizvodnje, retrived 23.08.2015.)

15. Sudarevic, T. (2011): Ekonomski faktori i marketing aktivnosti u razvoju organske poljoprivredne proizvodnje u Srbiji, pp. 19, Otvoreni Univerzitet, Subotica

16. Statistical Office of the Republic of Serbia (2014): Statistical Yearbook of the Repulic of Serbia, Belgrade

17. Višković M, Golub M, Đatkov Đ, Bojić S, Martinov M. (2012): Ukupan i raspoloživ prinos biljnih ostataka pšenice, sezona 2012. Savremena poljoprivredna tehnika, Cont.Agr.Engng. vol. 38, no. 3, pp. 189-286, Poljoprivredni fakultet, Novi Sad

18. Willer, H., Lernoud J. And Home, R. (2013): The world of Organic Agriculture: Statistic and Emerging Trends 2013, Research Institute of Organic Agriculture (FiBL) and the International Federation of Organic Agriculture Movements (IFOAM, 2013)

19. Privredna komora Beograd, (2014): Šanse za razvoj organske hrane u Srbiji (available at: http://www.kombeg.org.rs/aktivnosti/zadruzni_savez/Detaljnije.aspx?ve$\underline{\mathrm{za}=3260}$, retrived 28.09.2015.)

20. Informacija o aktuelnom stanju u primarnoj poljoprivrednoj proizvodnji, (2012): (available at: http://www.pkv.rs/pkv/files/poljo 2012 info.pdf, retrieved 29.09.2015.)

21. Poljoprivredni standardi (2011): Ekonomska analiza ukazuje na dugoročnu profitabilnost organske proizvodnje, (available at: http://www.poljostandardi.com/vest/ 
ekonomska-analiza-ukazuje-na-dugorocnu-profitabilnost-organske-proizvodnje, retrived 26.08.2015.)

22. P̌̌enica - Triticum Sp.L. (2014): (available at: http://agronomija.rs/2014/psenica/ retrived 23.09.2015.)

23. Povećane površine pod organskom proizvodnjom, (2014): (available at: http:// glassrbije.org/privreda/pove $\% \mathrm{C} 4 \% 87$ ane-povr\%C $\% \% \mathrm{~A} 1$ ine-pod-organskomproizvodnjom, retrived 22.09.2015.)

\title{
PROFITABILNOST PORODIČNIH GAZDINSTAVA U PROIZVODNJI ORGANSKE HRANE U REPUBLICI SRBIJI
}

\author{
Miljana Barjaktarovićs, Boris Kuzman ${ }^{6}$ Sonja Žarkovič ${ }^{7}$
}

\section{Rezime}

Prelazak sa konvencionalne na organsku proizvodnju u osnovi ima analizu isplativosti takvog vida ulaganja. Proizvodnja organske hrane je skupa ali su i cene organskih proizvoda visoke $i$ potražnja za organskom hranom svake godine beleži značajan rast. Analiza isplativosti ulaganja u proizvodnju organske hrane podrazumeva detaljnu analizu većeg broja faktora koji utiču na konačan ishod ulaganja. Efikasnost proizvodnje i racionalnost korišćenja raspoloživih resursa porodičnog gazdinstava merena je izračunavanjem profita gazdinstva metodom kalkulacije državnih subvencija $z a$ poljoprivedu $i$ vrednovanjem sopstvenih $i$ pozajmljenih resursa angažovanih $u$ proizvodnji. Shodno navedenom, rad ima za cilj da obuhvati i analizira najvažnije faktore ulaganja i uticaj njihovih promena na profitabilnost proizvodnje organske hrane u Srbiji.

Ključne reči: organska proizvodnja, rast, analiza profitabilnosti, cost-benefit kalkulacije

5 Redovni profesor, dr Miljana Barjaktarović, Alfa BK Univerzitet, Ulica Palmira Toljatija br. 3, 11070 Beograd, Srbija, Telefon: +381 112699 039, E-mail: miljana.barjaktarovic@alfa.edu.rs

6 Vanredni profesor, dr Boris Kuzman, Institut za ekonomiku poljoprivrede, Volgina ulica br. 15, 11060 Beograd, Srbija, Telefon: +381 63590 129, E-mail: kuzmanboris@yahoo.com

7 Asistent Sonja Žarković, M.A., Alfa BK Univerzitet, Ulica Palmira Toljatija br. 3, 11070 Beograd, Srbija, Telefon: +381 112699039 , E-mail: $\underline{\text { sonja.zarkovic@alfa.edu.rs }}$ 